\title{
Sex and Female Anatomy in the Urban Context in Reference to the Works of Chetan Bhagat
}

\section{Sourav Dey}

\begin{abstract}
Post colonialism suggests the studies comprising wide and vast era both at the local level of ex-colonial society and at the level of more general global development thought. In the postcolonial period one emerging issue, which becomes ubiquitous in almost every genre, is feminism. Feminism has left its impact on every literary genres, be it poems, dramas, short stories and novels. In post-colonial era a natural phenomenon which takes place, is the mobilization of people towards the urban places. Urban world itself symbolizes development, industrialization, jobs in the one side, but in the other side represents deception, betrayal and obviously contraption of sex. Sex and the female anatomy are burning and the most discussed motif in many contemporary works. Chetan Bhagat's works address the prevailing social condition and he portrays how the youth deal with the situation. Youth are very susceptible to sex. From the psychological perspective, youth suppress many of their emotions externally but all are reflected in their dreams. The high intensity of the sexual instinct is one reason why the adolescent is more prone to react to love than to any other emotion. This emotion finds expression in the form of excessive and almost obsessional attraction to the individuals of other sex. When it comes to other sex, female anatomy surfaces to prominence. Sex, sexualism and female body are very vividly depicted in the works of Chetan Bhagat. In his novels, male and female both take the role of indulging in sexual escapades. The present paper will investigate and assess whether the female, their bodies, sexualism form a major conception in the post-colonial era as observed in the works of Chetan Bhagat.
\end{abstract}

Keywords: Post colonialism, Feminism; Sexualism, Female Anatomy, Popular Literature.

Sex, erotic escapades and female anatomy have always been a matter of sensation for time immemorial in our civilization. In post-colonial literature, be it any genre, eroticism is depicted in the literature. Before we broach into the discussion, certain concepts i.e. post colonialism, feminialism and popular literature must be taken into consideration. Postcolonial studies suggest the studies comprising wide and vast era both at the local level of excolonial society and at the level of more general global development thoughts. Post-colonial writings are regarded as the historical creator of the era since it consists of the literature, which comes after decolonization. Post-colonial writers involve themselves in widening up the probabilities of a new language and a new way of beholding the world. The corpus of post-colonial literature can be considered as a medium of restrain from the former colonization. The main importance of the motif lays on the issues like identity, national and cultural heritage, human relationships and emotions. In Indian context, a paradigm shift took place in the Post-Independence period and the novels extensively deal with the social evils, deeply rooted in our society. While discussing about the social issue, the feminism is an 
emerging issue in the works of the novelists. Women were always at the mercy of men. Women liberation and empowerment, the two subsequent concepts started rumbling in the content of every literary genre, be it poetry, drama and novels. Feminism is an assortment of diverse, multi-layered, complex and often contradictory ideas. The origin of the term 'feminism' is arguable. It was traced back to 1871, when it was used as a medical term to define symptoms of feminization of the bodies of male patients. Post-colonial feminism intends to address the issues related to women from diverse national and cultural contexts. In this post-colonial period, one of the most well discussed genres is Popular literature, which has come extensively into existence and it itself is very appealing and acceptable to the large mass. Popular literature includes those writing, intended for the masses and those that find favor with large audience. Popular literature can be distinguished from artistic literature in that it is designed primarily to entertain. Popular literature, unlike high literature, generally does not seek a high degree of formal beauty or subtlety and is not intended to endure. With the Industrial Revolution, works of literature, which were previously produced for consumption by small, well-educated elites, becomes accessible to large sections and even majorities of the members of a population. The most important motif in the domain of popular literature is the romance. The romance has been flourishing from the middle Ages to the present. The very motif explicitly consists of sex and female anatomy, which occupy a certain portion in this genre. Besides this, the very motif caters to the taste of masses.

In India, one might associate popular literature with the likes of Chetan Bhagat, Preeti Shenoy,Amish etc. Among them, the most popular and most discussed is Chetan Bhagat. Chetan Bhagat is a profound and prolific writer of popular literature. He has ten main novels and two non-fictions to his credit. Chetan Bhagat has depicted the urban lives. These very lives are full of jocund of spirit and joyousness. Urbanity, in one hand, presents the development, industrialization, better job opportunity etc., but in the other hand, promotes cash nexus, dishonest politics, corruption, nepotisms, betray in love, sex, immorality from traditional point of view and many more. Prakash and Pandey have observed that a painter delineates the beauty of body and expression with his pencil and brush using different colour patterns in visible form whereas a writer presents the same with the power of words in the mind of his readers. Shekespeare's Rape of Lucrece, John Keats' The Eve of St. Augus are literary works in which we can see the beauty on mental screen with the word power used by them. Chetan Bhagat uses modern adjectives to elucidate the carnal beauty. (Bhagat, 2016) Chetan Bhagat has the proclivity to transform the society and he perceives that it is the youth, who can only dedicate to this prolonged and strenuous deed. The youth are very susceptible to sex. From psychological aspect, an adolescent is very sensitive to any injury to his prestige. Many of his emotions, he suppresses externally but they find expression in the form of daydreams. The high intensity of the sexual instinct is one reason why the adolescent is more prone to react to love than to any other emotion. This emotion finds expression in the form of excessive and almost obsessional attraction to the individuals of the other sex. When it comes to other sex, female anatomy surfaces to prominence. Sex and female anatomy are depicted in many of Bhagat's novels. Male and female both take the equal role of indulging in sexual escapades, and eventually, sex is regarded natural requirement for human being, and aesthetically, it has its own sublimity.

It is obvious that Bhagat's novels are not much interested in literary issues in the traditional sense. The very subject matters and treatment require more of a sociological methodology spiced with interdisciplinary approaches. Qualitative approach has been adopted for close study of the novels of Chetan Bhagat to comprehend the germane issues like sex, erotism and the exposure of female body. A dedicated endeavor has been taken to dig deep into novels of Chetan Bhagat to find out the magnitude of the issues surfaced and the eventual impact of those on the young generation. I will visit libraries to find out pertinent materials related to my research topic in form of books of authors other than Chetan Bhagat 
who have worked on similar issues. Besides these, I will read research articles - both available in the libraries and online articles.

Bhagat has delineated various love affairs in his different novels. The most interesting thing, the love affairs are different from each other in different novels. In his works, love is an eventual mingling of the two, male and female protagonists, in a mutual consent of their own. All the female characters in his novels have the natural propensity to involve into erotic escapades. In 2 States, the protagonists Ananya and Krish studied in the same college IIMA in Ahmedabad. The female protagonist was presented in sensual way, as if; it twanged at the hearts of young people. "Her waist - length hair rippled as she tapped the steel plate with her fingers like a famished refugee. I noticed three black threads on the back of her fair neck" (Bhagat, 2009, p. 9). Author has depicted picturesquely the beauty of the hairs movement when she moved to eat something from the plate. Furthermore, he, very delicately, draws the attention of the readers to the threads on her back. Here, the author obliquely illuminates the fairness of the back of the girl by indicating that even the three black threads are visible there. Ananya is different from most of the students. He has very artfully suggested that

Most IIM girls above shallow things like make up,fitting clothes, contact lenses, removal of facial hair, body odour and feminine charm. Girls like Ananya, if and when they arrive by freak chance, became instant pins - up in out testosteronecharged, estrogen-starved campus.(Bhagat, 2009, p. 9)

Ananya is par-excellent and that is very smartly established. Her very presence has not only triggered sensation at male students' hearts but also her presence creates jealousy in female. He has very subtly hinted at the prominent characteristic of female. He has very artistically drawn the beauty of Ananya as if the readers relish the succulence of his picturesque depiction. Krish said,

She had perfect features, with eyes nose lips and ears the right size and in the right places. That is all it takes to many times? Her tiny blue bindi matched her sky- blue and white salawar kameez. She looked like Sridevi's smarter cousin, if there is such a possibility. (Bhagat, 2009, p. 9)

He has injected sensualism using various devices. He has deliberately employed the colour red to ignite a sense of sensation in the sequence of events. "She wore a red and white tracksuit" (Bhagat, 2009, p.19). In our society, there is a restriction for women about their dress code. They are always advocated what they should put on when they stay at home and when they go out. But for men, hardly any dress code is prescribed or proscribed. It is vindicated when Ananya suggested to go to Rambhai, but Krish, despite modern college student, saw her shorts and indirectly asked her to change. But, she did not listen to him and being steady and fully conscious what she was, retorted in his face, "Excuse me. Is it a Delhi thing or a Punjabi thing? Controlling what women wear? Enough people stare within campus. I'm fine, let's go, she said and walked towards the Campus gates." (Bhagat, 2009, p.15)

Bhagat has delineated a very realistic picture of what is taking place in hostel. Girls enter the boys' dorm and they are having sex. He did not scruple to picture all details. In these sequences, the sensualism pervades throughout the scene. The male protagonist, Krish also loved to enjoy the bare beauty of women even in lugubrious condition. He pondered, "She sat up and wore her top. She stepped off the bed to wear the rest of her clothes. Despite the serious mood, I could not help but notice how wonderful women looked when they change. I'm going to my room. Enjoy your nap" ( Bhagat, 2009, p. 41). Sigmund Freud, the founder of the school of psychoanalysis, believed the sex motive is due to the excretion of a gland. In the male, it is caused by the excretion of the sex glands while in the female due to 
the ovaries. Sexual indulgence, which is kindled by either the beauty or feminity of the female or the masculinity and strength of the male, acts as stimuli besides the organs. The proximity of a member of the other sex may also create sexual urge. Krish became horny at the sight of her lips. He was fantasying how to kiss her. He said, "I had been staring at her lips, researching ways of kissing her." (Bhagat, 2009, p. 28)

With the passage of time, they interacted with themselves more liberally. Krish became more possessive and his desire became stronger. The study became wearisome and laborious. He needed to put double effort to draw his attention into single concentration. He essentially, sought to extract himself from this monotonous life and the only way out he found, was watching her succulent lip and planting a kiss on it. He said,

First, I have to force myself to pay attention to these boring cases. Second, I have to avoid looking at your face as much as possible because when I look at your face, all I want to do is kiss you. But we have this stupid just -friend deal and you are all cool about it and so that leaves me whipping my mind to study nicotine free cigarettes and not think about your lips. (Bhagat, 2009, p. 32)

Ananya is a smart and modern girl. Actually, she perceived an inner propensity but she did not receive any response earlier. Now, her inert sensation reigned supreme and she approached to him and planted a kiss on his lips though Krish was hesitant. It was so exuberant for them and they counted the time too. He said, "I froze, Ms. Swaminathon didn't as she came close to me. In a second, her Footi-loar lips were on mine, we kisses for three second" (Bhagat, 2009, p. 32). Chetan Bhagat has retained his own mark here. He could have stated in another way, but he did not miss the chance of illuminating the juicy lips of Ananya. He did not employ the word like 'smooch' but he implicitly suggested the softness and taste of that kiss which lasted for three seconds. This three second of kiss occupied their mind for long time. Both of them were essentially seeking exposure again. They, as natural reaction, endeavored to show their feigned apologetic expression to each other, but the insatiety resonated in both of their hearts and in two weeks, they quenched their insatiety.

Krish and Ananya studied together in Krish dorm and they had sex in two weeks. Author has brought out the realistic facts with authenticity. It is evident through the words of Krish "Needless to say, one thing led to another and within two weeks we had sex. You put a boy and girl in a room for a week and lots of boring books and sparks are sure to fly" ( Bhagat, 2009, p. 35). Here, he has stated this erotic scene not in a negative sense. They felt boredom and they needed break. They felt orgasm because of proximity, their mating broke that boredom, and they became rejuvenated and eventually, concentrated in their studies. "Absence makes love grow fonder". This very proverb is most suitable. krish and Ananya had not had sex for long time. They had suppressed their latent desire. The monotony of the city atmosphere and the tedious job in the bank made him find in thralldom. He wanted to slit open the curtain of bondage and breathe a fresh air of freedom. Subsequently, when they came in close proximity with each other in a closed room and their ingrained longing blurted out. They had sex to escape from the tedious and tepid life. Krish said, "Our love making was more intense, not only because we did it after a long time but also because we were doing it in this stuck-up city for the first time." (Bhagat, 2009, p. 120)

In Three Mistakes of My Life Chetan Bhagat could not help describing the mystery of female anatomy. Here, the trio Gobind, Omi, and Ishaan went to Australia for better opportunity of Ali who was prodigy, an extremely talented batsman. They decided to enjoy the natural beauty of Bondi beach, but, when they came to learn about the presence topless women, they became double excited. The conversation between Gobind and Omi serves the purpose.

That is, those who were women. Gorgeous and topless. And if you have never seen a topless women in your life before, places like this did things to you. Wow, you can actually see their ni... wow .There are a hundred women here. So we have two 
hundred breasts to look at. Having grown up in a place where sleeveless blouses cause scandals, tops-off is what an MBA type would call a paradigm shift. (Bhagat, 2008 ,p. 172)

Sensualism pervades, but here Chetan Bhagat has elaborated the events as opening up the mystery. He has always portrayed female in a sublime way. Female has certain reverence, which one can find, when they deliberately capitulate themselves to opposite sex. In the Bondi beach, the lovely, exotic natural ambience, essentially, is aggraded with presence of topless female. But, Chetan Bhagat did not let it grow in the way, as if, readers found some vulgarity. He enhances scintillating atmosphere by conflating nature and human, but he draws the girdle when required. Gobind said,

It is funny but the bare-breast became routine in a few minutes. I guess you get used

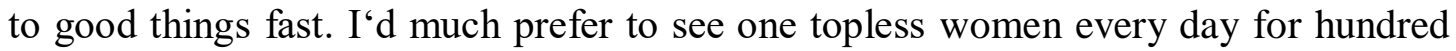
days, rather than a hundred at once...I noticed a brunette in an umbrella next to me. She wore a shirt on top of her bikini and had her back to me. Her long black hair fell over her thin back. She applied something in her hair, probably oil or lotion or any such thing that girls feel is essential to their existence. ( Bhagat, 2008, p. 173)

Sensualism is pervasive in this description. However, a further study will reflect an unconscious pain striking at the protagonist's heart and he could not enjoy the sexy, magnificient natural phenomenon any more. When Gobind said,

Something hurt inside me. I felt like someone pounded my chest. The brunette rubbed her hair exactly like Vidya...Ramdom thought circulated in my head, like oiled fingers in hair. Woundn't it be nice if Vidya was here? Isn't this what she longed for most? (Bhagat, 2008, p. 173)

The whole atmosphere is sensual and sexual, but, protagonist Gobind didn't drive into vulgarity, rather the very thought Vidya commanded over his thought process and hooked him in the center of his periphery.

"If they be two, they are two so

As stiff twin compasses are two

Thy soul the fixed foot makes no show

To move, but doth, if th'other do."

( Donne, 1633, p. 39).

Donne states that lovers are two souls, if they have faith and true love for each other, whenever they move, how far , they move, they must come to each other as their center is fixed just like a compass.

Well clad beauty of Vidya has very elegantly been portrayed and readers can perceive Gobind's mesmerized and gobsmacked feeling, watching at pure defined attired Vidya and her matching adornment. Gobind said,

She wore a new purple and white bandhini salwar kameez today. Her necklace had a purple teardrop pendant and matching earrings. She had freshly bathed. Her hair smelt of a little bit of Dettol soap and well her. (Bhagat, 2008, p. 187)

Vidya female protagonist has, actually, a proclivity towards breaking her virginity. She was virgin and she wanted to get rid of that status. It is not that she would indulge in relationship and break that status; rather she built a serious relationship and proceeded gradually. She sensed the positive vibes from Gobind, despite his apparent negative responses. Vidya said,

Did you really miss me? She said and put her palm on my hand,

I pulled it back in reflex. She looked surprised.

I am sorry, Vidya. I shouldn't. I have my business to focus on and this is really not my thing, but... ( Bhagat, 2008, p. 188)

Vidya, by her feminine instinct, felt and also realized that a sense of guilt occluded his spontaneous flow of expression and eagerness of his heart and mind. Gobind said, 
It's not ok. I don't have time for emotions, I said in firm voice and this is not the place anyway. My best friend's sister?... be serious . Vidya, this is not right. I am your teacher, your brother trusts me as a friend, I have responsibilities - loans, business and a mother. You are not even eighteen.(Bhagat, 2008, p. 188)

Vidya realized the twangling sound of his heart and seduced him.

She threw a tiny spit ball in the air. She opened her mouth and brought it close. Her lips were eight millimeters apart from mine.Soon the gap reduced to zero. I don't know if I came towards her or she came towards me. The tiny distance made it difficult to ascertain who took the initiative. I felt something warm on my lips ...(Bhagat, 2008, p. 189)

Vidya continued with her seduction. She, essentially, wished to extricate Gobind from his presumptive bindings and make him free and true to heart. She was successful since she had been able to remove the big stone which chocked his spontaneous flow of emotion and he was swayed by her effort. Gobind said,

I'd love to say I say stars and heard sweet music during my first kiss. But the dominating background sounds were (a) Vidya's mom's pressure cooker whistle from downstairs in the kitchen, (b) the campaign sounds from the auto's of various parties for parties for the upcoming elections and (c) the constant buzz of mozzies. But when you are in the middle of a kiss, sound and sight get muted. I checked once to see if the other terraces were empty. I closed my eyes. (Bhagat, 2008, p. 189)

Gobind wanted to stop it but, he could not. He said "Vidya, what are you doing? I said not letting her go. I could not stop.” (Bhagat, 2008, p. 190) From onwards, kissing appears a normal daily occurrence. They did this in a balanced way. This kissing is a gateway of avoiding boredom and rejuvenating themselves. Gobind said,

However, we made up for it in the next class where we spent the first ten minutes kissing and the rest discussing her mistakes. When, we felt desire, we kissed. When we felt guilt, we studied. Somehow, we balanced mathematics and romance within the hour... (Bhagat, 2008, p. 202)

On birthday of Vidya when she reached eighteen, she had cherished the plan of stepping cross the threshold of virginity. This time eroticism surged over her head and she executed her plan. Chetan Bhagat has employed background music to provide a filmy atmosphere and it renders another dimension in setting the event. The music continued,

I can't deny what I believe

I can't be what I'm not,

I know this love's forever

That's all that matters now. (Bhagat, 2008, p.204)

Vidya took the charge, and Gobind was swayed to do the thing before he realized. He said,

But she continued to kiss me as she unbuttoned the rest of her top. She pulled my fingers towards her again...By this time, my hand was in places impossible to withdraw from for any guy. So, I went with the flow feelings, desire, nature or whatever else people called the stuff that evaporated human rationality. (Bhagat, 2008, p. 204)

They have reached the pinnacle of erogenous zone and after consumption of each other, they both calmed down with full satiety. Vidya could not help expressing her exuberance and she let Gobind know that he did not feel guilt since she was then eighteen. She expressed her exuberance by stating, "Wow, I am an adult and am no longer a virgin, so cool. Thank God, she said and giggled. See, I still have goose bumps; she said and lifted her arm. Little pink bumps dotted her flowless, fair skin" (Bhagat, 2008, p.205). Pandya has opined that for the current generation lovers, sex is a way of expressing their love for their partner and they do it before the necessary social rituals. They look at sex as an expected thing in love. That is why; they indulge in sex every now and then. At last, they either get 
married or committed to live together. By this portion, Bhagat has invited a big signal of examination on the chastity and faithfulness of the girls in the new era. (Bhagat, 2015)

Radhika in One Indian Girl, is very bold, intellectual and highly efficient in her walks of life. She was very good at studies and always stood first. She studied in IIM Amedabad. Despite that, she didn't get noticed for the talent she possessed. In frustration, she said, "In school, people either didn't notice me or made fun of me" (Bhagat, 2016, P. 19). Here, Chetan has not presented her, like in his earlier novel, in a scintillating highly salacious and succulent way. Instead, she appeared before us as nerd, this is how she described herself, "At SRCC, I realized that I was nerdier than even the regular nerds." (Bhagat, 2016, p. 19)

Chetan has leveraged the technique of flash back, which, very conveniently, takes the readers through her memory lane to her past account, and the readers came to learn about her anecdotes. Chetan has portrayed Radhika as a highly intellectual girl but she was not interactive with the people surrounding. She was feeling lonely and she was made butt of joke by her fellow friends. She was not attractive as well. She was conscious of it. Eventually, she confined herself to her studies. She self-confessed, "I preferred the former. Hence, I stayed in background with my books." (Bhagat, 2016, p. 19)

An incident which, apparently incurred a sensation in her heart, but , turned out to her an utter disappointment and insultation and that was her turning point or, rather say, decision consolidating moment to devote herself to academics. She was conscious about her body, and eventually, she became habituated with it. When people said something in an insinuating way, she presumed the meaning of it. Her elder sister Aditi suggested her to get married at her age, which was 21. Aditi did explain why she said so, but she made out the meaning of it. She said, "She never explained. I guess she meant for someone as nerdy as me or as wheatish as me or someone whose breasts weren't the size of footballs, as Punjabi men prefer." (Bhagat, 2016, p. 19)

It may be Aditi, her elder sister, out of casual sense and being her elder sister's sense of responsibility, might have suggested her for marriage. But from school level, she was humiliated for her physical look and the unattractiveness in her physicality. Subsequently, she was suffering from inferior complexity. She felt the lack of salaciousness in herself and she realized men did not like her, they did not prefer to hook up with her. This very judgment about her always reverberated in her sub-conscious mind.

Radhika signed her first assignement and obviously, she became very happy and full of jocund of spirit. She wanted to express her excitement by sharing with others, but she could not share it with her parents since they lived in India and it was night time. She, subsequently, spurted out her exuberance to her intimate friend Debu. As usual, they met in restaurant. Like Vidya, Radhika too had the urge to quench her erotic inclination. She showed her bare waxed thighs to seduce Debu. She thought, "My dress ended high on my thighs... I wondered if he noticed" ( Bhagat, 2016, p. 52). She wished to celebrate her success for kissing. It was a natural reaction at this age and she was very eager to do this, but her culture restrained her from fulfilling her long ingrained desire. She considered that it was unethical on girl's part to approach for kissing. Her thought reflected this,

Yes, we have, but why haven't we kissed yet? Is it wrong for a girl to think that? Should he be asking me that instead? Where are the rules? How can a girl admit she is thinking about kissing? Isn't that what super slut do? This very thought haunted her and she could not attempt to kiss him. (Bhagat, 2016, p. 53)

She was always regarded as nerd and she was not physically attractive towards the eyes of male or even female, rather she appeared boring to all. That consciousness always had an influencing impact on her. She continued to bother about her body parts. She again pondered, "Did he notice my legs yet? Did dinner make my stomach less flat? Are my boobs in place?" ( Bhagat, 2016, p. 54) 
Radhika was very persistent girl. She was performing great in her office. Her performance always snatched the appreciation from her fellow colleagues. She showed her waxed thighs to Debu whenever she had a chance. Her endemic desire finally met its fulfillment. Debu, deliberately massaged her feet and he continued to rise up from feet to the thigh and finally they were swayed by their sexual indulgence. She said,

He kissed my nipple. He moved up and kissed my collarbone. He kissed my chin and then my lips for several minutes... he tugged at my panties. My hearts beat fast. Was I really going to get fully naked in front of a man?...He removed his trousers and underwear. I had not seen a naked man so up close. (Bhagat, 2016, p. 59)

She was enjoying this erotic pleasure, but she had cherished a desire to examine the male anatomy. She was, by nature, a good student, and it was evident when she said in her heart, "I wanted to get a good look, more as an anatomy lesson" (Bhagat, 2016, p. 59). Radhika is essentially a 'sanskari' girl who had not lost her virginity until that moment. Her consciousness posed questions of her procedure towards this escapade. She pondered that this copulation might malign her sweet, pure reputation. She worried, "The good girl in me wondered if he would judge me for it." (Bhagat, 2016, p. 59).

Chetan Bhagat has delineated this extreme moment of human life very elaborately with minute details. He has brought up in the light of pleasure one derives out of one's first mating. He has not defined it in the line of morality, rather he has emphasized on the erotic pleasure that human also requires. Human being sans sex or this erotic pleasure may have detrimental effect on their mentality if human is not trained in certain way. He has illuminated that pleasure rejuvenates their energy level and replenishes them so much that they get into their job with full gusto. Radhika confessed, "Every flick transported me to a state of extreme pleasure. Why don't people do this all the time? Wow, why didn't anyone tell me sex feels so damn good?" (Bhagat, 2016, p. 59)

Chetan Bhagat has very delicately portrayed the entire erotic scene. He was very realistic in his approach towards any analogue. Radhika was virgin for long time in comparison with her fellow mates. Now, she found her opportunity to explore and relish her optimum pleasure out of sex and Chetan Bhagat has brought the analogue of her prolonged cherished desire of sex and the final consumption of it, with the long wait for a big Salman or Shah Rukh movie for months and final watch of the movie. She said,

So, how did I feel after having sex the first time? Well, you know how you sometimes wait for a big Salman or Shah Rukh movie for months and then it finally arrives? You go for the first day first show, and then the movie is not bad, but not so great either. (Bhagat, 2016, p. 60)

Radhika, eventually, decided to shift her job and joined another branch Goldman Sachs in Hong Kong, where she also exhibited her essential excellence in work dealing with the colleagues and cracking a business deal with enormous margin. It was her intelligence and her diligence, which brought her very close to her boss and her fellow colleagues. She performed a fantastic job in solving a business issue with yielding a huge profit and she received a treat in form of trip to Pengalusian Island in Philippines. Neel and Radhika enjoyed the evening beauty of natural phenomenon. The waves of the sea touched their feet. A sensation also began rippling in their hearts too. Somewhat obstructed that urge to ooze out from their hearts and to allow them to mingle with each other. Something acted like emulsion, which, somehow, separated those two bodies to be conflated. When she dabbled her feet in the water and coincidentally, their feet touched each other. That touch rinsed the thin layer of emulsion of hesitation between them and they were swayed with their emotional drive. She described, "He kissed me long and deep as dozens of waves broke and touched the soles of my feet...Goosebumps broke out all over my body if he could kiss like ... his other hand went to my thigh and my heart started to thump louder." (Bhagat, 2016, p. 155)

Without exception, the great mystery and reverence, which Chetan Bhagat attributes to 
female anatomy, are also elaborately described here. Chetan Bhagat has illuminated the reality that actually takes place in a secluded island where adult male and female are emotionally thirsty of sap, due to their detachment from their respective near beings. Chetan Bhagat has depicted with minute details, the mysterious transformed physic of Radhika whom people abhorred most in her schooling and college days. Her vivid description of optimum pleasure follows,

His hand went behind me and unhooked my brain one snap. My breasts felt the cold breeze.... Took a breast in his hand. I could feel myself melting all over. When my hand brushed over his shorts, I knew he was as turned on as I was ,if not more. His mouth was on my breasts. I lifted my hips and he pulled down my underwear. Then we were both naked on the sandy beach. (Bhagat, 2016, p.155)

In the midst of supreme moment of excitement, her love for Dubu restored back to her mind. She did not wriggle out of the sweet memories of Debu. In fact, she spent many sweet moments with Debu during her staying in U.S.A. After a long lacuna, she, actually, in the supreme moment of concupiscence, felt the quench of her thirst and a comparison bobbed up in her mind. She felt,

The pleasure became unbearable. I arched my back. Debu had gone down on me before. However, this was a completely new level of sensation and pleasure. If Debu was French fries, this was a gourmet six - course meal. If Debu was bear, this was champagne. If Debu was a boat, this was a luxury cruise. (Bhagat, 2016, p. 155)

Chetan Bhagat proceeds further to execute this erotogenic moment to lead the final consumption of fornication. Every layers of sensation that one feels from commencement to the final sublimity, is demonstrated. Radhika felt'

He moved with gentle and firm strokes. I felt the built-up again and I came a second time, more intensely than the first. My body shook, I closed my eyes, and I blacked out for at least thirsty seconds. This one orgasm had the intensity of ten orgasms.( Bhagat, 2016, p.156)

This erogeneity and making love are not put forth in the light of animal pleasure, rather Chetan has elevated to the level of divinity and sublimity. Parveen \& Gupta found that sex is not only the way to fulfill chief creative functions of man and women, but the sexual experience is a door to new realms of consciousness, and initiation into divine mysteries, the mystery of the other world that is close behind us.(2015,p.3) Radhika herself realized this, "I could not. I simple nodded. It wasn't just good. It was divine, sublime, insane, Philippineexclusive-island-level-good." (Bhagat, 2016, p. 156)

The cultural heritage, which she derived from her family and society, formed a certain inner consciousness, that gradually took her in control, and she herself chided her blalantly by saying, "He's fucking married. He has two kids, there is a wife. They are all waiting in Hong Kong, where both of you live" (Bhagat, 2016, p. 162). When Radhika actually met Kusum, Neel's wife she felt awkward and guilty simultaneously. To her, Kusum appeared pious and a pristine beauty with her code of dress, she said in her mind, "God, she is actually a nice person. She had praised my simple white lace dress, even though she probably wore a designer Prada or Gucci outfit herself. She was not a bitch. And that just made me feel worse" (Bhagat, 2016, p. 162). When Kusum genuinely praised Radhika for her dress and her lovely body, fit for this clad. She started scanning her body and comparing hers with Kusum. She observed, "She seemed fit too. I looked at her face. She was pretty, fair and had high cheekbones. I would kill to look like her at forty. I noticed she had a small bust. My boobs were better." (Bhagat, 2016, p. 162)

Chetan, as usual, did not present the female anatomy in the portrayal of vulgarity; rather he has elevated it to a sublime stature from an artistic perspective. Kusum appreciated Radhika's physic and her body shape and she told Radhika that Radhika was very beautifully 
suitable for the dress she wore and Kusum herself might not fit into that dress code due to the limitation in her physical stature. Basically, the physical outfit, which makes human more attractive and attentive, is expressed through this. An aesthetic sense is more strongly showcased, instead of vulgarism.

Chetan Bhagat is very frank and open in portraying the erotic scene in his novels. He is not essentially sexualist, instead, he has treated his subject matter with more liberation and greater fessibility. He knew the indispensability of sex in human life. Chetan Bhagat did not present sex in an extravagant way or give sensation to the hearts of the readers. He treats sex purposively as it, according to him, leads them to another state of consciousness, a sublime realm. Sex is not only the medium to quench physical hunger, but the sexual experience is a gateway to a pinnacle of consciousness, and a commencement into a realm of sublime mystery. He believes that deepest secret of life can be unraveled through sex and therefore it is the rudimental for complete life. He perceives that for the acquirement of actual happiness in life, the sexual harmony is aesthetically essential.

In India, the temples are sculptured with different poses and postures of sexual activities. They have essentially an inherent meaning and they bear a value and significance of our culture. However, the reflection of that heritage in the literary works incurs rage, criticisms and derogatory comments like ruining the hoary cultural heritage of a great nation in many literary figures. Sex before marriage and sex with multiple persons are the common theme of the novels today. He is vindicated bold here in treating sex and exploring sexual relationship among his novels characters. He targets those readers who have just reached the age of adolescent or youth and are aspirant of higher education or becoming well established in their respective field. Most of the readers have hidden longing to stare at and chat with their opposite sex. While they are going through the novels, they feel that their long suppressed desires, lying inert in their hearts, are reflected in the sequence of events and that desire, Bhagat has engineered in his works. In this sense, Chetan is a revolutionary writer who has little parity with D.H Lawrence. However, we cannot match him with D.H Lawrence whose works are by far a per excellent so far his erotic description is concerned. Chetan has depicted sex, eroticism, but he has no inclination to advocate the youth about how and where to plant well kiss or about the performance of sexual activities, rather he has given an outlet to their prolonged hard-pressed desire without guilt.

\section{References}

\section{Primary Source:}

Bhagat, C. (2008). The Three Mistakes of My life. Rupa \& Company.

Bhagat, C. (2009). 2 States: The story of my marriage. ( $2^{\text {nd }}$ ed.). Rupa \& Company.

Bhagat, C. (2016). One Indian Girl. Rupa \& Company.

\section{Secondary Source:}

Perveen, A \& Dr. Gupta, Tanu. (2015), Love and Sex: Free Treatment in Chetan Bhagat's Novels, The Criterion An International Journal in English, 6(2), p .p 1-6.

Prakash, S \& Dr. Pandey, R. (2016). Delineation of erotic Scenes in the Novels of Chetan Bhagat , Paripex -Indian Journal of Research ,5(1), p.p 269-274.

Dr. Pandya, S.R (2015). Women Empowerment In Chetan Bhagat's Novels, IJARIIE 1(2) p.p 368-370. http://www.ijariie.com 


\section{Bio-note}

Mr. Sourav Dey (M.A, B.Ed, Research scholar) presently works as an Assistant Teacher in the English Department of Kanthalberia Harakumar Vidyaniketan H. S School, Nadia,West Bengal. His areas of interest are Cultural Studies, Feminism and Indian Writing in English.

Email id: soubum.85@gmail.com 